\title{
Cost-effectiveness of screening for hepatocellular carcinoma: putting the cart before the horse
}

This article was published in the following Dove Press journal:

Risk Management and Healthcare Policy

8 August 2012

Number of times this article has been viewed

\author{
Alain Braillon \\ GRES, Public Health, Amiens, France
}

Correspondence: Alain Braillon 27 rue Voiture, 80000 Amiens, France Email braillon.alain@gmail.com
Ruggeri has recently reviewed the cost-effectiveness of screening for hepatocellular carcinoma (HCC). ${ }^{1}$ However, evidence for effectiveness is still lacking, with only two randomized trials available, both from China, one of which is negative and the other positive but with several major flaws. ${ }^{2}$ Only observational studies are available from developed countries, and conclude that screening improves survival, despite raw data showing that screened patients die younger than nonscreened patients, (length time and lead time biases). ${ }^{3}$ The National Cancer Institute recommends that "based on fair evidence, screening would not result in a decrease in mortality from HCC ... based on fair evidence, screening would result in rare but serious side effects". ${ }^{4}$

\section{References}

1. Ruggeri M. Hepatocellular carcinoma: cost-effectiveness of screening. A systematic review. Risk Manag Healthc Policy. 2012;5:49-54.

2. Lederle FA, Pocha C. Screening for liver cancer: the rush to judgment. Ann Intern Med. 2012;156: 387-389.

3. Braillon A. Screening for hepatocellular carcinoma: from lack of evidence to common sense. Hepatology. 2010;52:1863-1864.

4. National Cancer Institute, US National Institutes of Health. Liver (hepatocellular) cancer screening (PDQ $\left.{ }^{\circledR}\right)$ Available at: http://www.cancer.gov/cancertopics/pdq/screening/hepatocellular/HealthProfessional/ page2 Accessed June 26, 2012.

\section{Publish your work in this journal}

Risk Management and Healthcare Policy is an international, peerreviewed, open access journal focusing on all aspects of public health, policy, and preventative measures to promote good health and improve morbidity and mortality in the population. The journal welcomes submitted papers covering original research, basic science, clinical \& epidemio- logical studies, reviews and evaluations, guidelines, expert opinion and commentary, case reports and extended reports. The manuscript management system is completely online and includes a very quick and fair peerreview system, which is all easy to use. Visit http://www.dovepress.com/ testimonials.php to read real quotes from published authors. 